\title{
Bacterial Invasion in Root Cementum and Radicular Dentin of Periodontally Diseased Teeth in Humans*
}

\author{
A Reservoir of Periodontopathic Bacteria
}

\author{
Patrick A. Adriaens, $†$ Jan A. De Boever $\ddagger$ and Walter J. Loesche§
}

Accepted for publication 6 April 1987

\begin{abstract}
IN THIS STUDY THE VIABILITY AND THE distribution of bacteria within the radicular dentin and pulp of periodontally diseased caries-free teeth were studied. Healthy teeth served as controls. Samples were obtained from the pulp tissue and from the radicular dentin. Dentin samples were taken from the interdental surfaces in the subgingival area. Starting from the pulpal side, three to five successive dentin layers of approximately $1 \mathrm{~mm}$ thickness were sampled. The samples were processed and cultured using an anaerobic technique. Bacterial growth was detected in $87 \%$ of the periodontally diseased teeth. In $83 \%$ of the teeth, bacteria were present in at least one of the dentin layers. Fifty-nine percent of the diseased teeth, from which the pulp tissue was cultured, contained bacteria in the pulp samples. The mean bacterial concentrations in the pulp and dentin layers ranged from 1,399 to 16,537 colonyforming units (CFU) per mg of tissue. These concentrations were 259 to 7,190 times greater than concentrations found in healthy teeth. It is suggested that the roots of periodontally diseased teeth could act as bacterial reservoirs from which recolonization of mechanically treated root surfaces can occur, as well as infection of the dental pulp. These findings might change current concepts concerning root surface debridement in periodontal therapy.
\end{abstract}

The bacterial reservoirs from which periodontopathic bacteria recolonize subgingival root surfaces after periodontal therapy are not completely known. Suggested sites that could act as bacterial reservoirs are the supragingival plaque, the saliva, the oral mucosal surfaces, including the dorsum of the tongue, the tonsils and the buccal mucosa, ${ }^{1,2}$ cemental resorption lacunae ${ }^{3-5}$ and the soft tissue wall of the periodontal pocket.

Invading periodontopathic bacteria have been dem-

* This work was supported by U.S. Public Health Service grant F05-TW03311 from the Fogarty International Center (National Institutes of Health), by U.S. Public Health Service grant DE02731 from the National Institute of Dental Research and Belgian Medical Research Council grant 3.0028.84 from the Nationaal Fonds voor Wetenschappelijk Onderzoek.

† University of Michigan, School of Dentistry, Department of Oral Biology and Dental Research Institute, Oral Bacteriology Laboratory, Ann Arbor, MI 48109. State University of Ghent, School of Dentistry, Department of Fixed Prosthetics and Periodontology, University Hospital, De Pintelaan 185, B-9000 Ghent, Belgium. Recipient of a Fogarty International Research Fellowship.

$\ddagger$ State University of Ghent, School of Dentistry, Department of Fixed Prosthetics and Periodontology, University Hospital, De Pintelaan 185, B-9000 Ghent, Belgium.

$\S$ University of Michigan, School of Dentistry, Department of Oral Biology and Dental Research Institute, Oral Bacteriology Laboratory, Ann Arbor, MI 48109. onstrated in the epithelium and in the underlying connective tissue in cases of acute necrotizing ulcerative gingivitis, ${ }^{6-8}$ advanced adult periodontitis ${ }^{9-15}$ and juvenile periodontitis. ${ }^{15-18}$

In the radicular hard tissues, i.e., cementum and radicular dentin, of periodontally diseased teeth, the presence of invading bacteria has been reported occasionally. Under an intact surface, invading bacteria were found in root cementum. ${ }^{19,20}$ Miller $^{21}$ described bacteria invading the radicular dentin of periodontally diseased teeth. This observation was confirmed in light microscopic studies on human material. ${ }^{22,23}$ Recently, using scanning electron microscopic and light microscopic techniques, Adriaens and De Boever ${ }^{5}$ demonstrated bacteria invading the radicular cementum and the dentinal tubules of the radicular dentin of periodontally diseased, caries-free human teeth.

The present bacteriological investigation was undertaken in an effort to determine the numbers and distribution of bacteria invading the roots of periodontally diseased, caries-free human teeth.

\section{MATERIALS AND METHODS}

Materials. An experimental and a control group of teeth were studied. Sixty-nine periodontally diseased, 
caries-free human teeth were in the experimental group. These teeth had to be extracted due to extensive loss of periodontal supporting tissue. The following selection criteria were used: (1) probing attachment loss of $4 \mathrm{~mm}$ or more, (2) bleeding upon probing and (3) absence of any clinically detectable coronal and radicular caries. The loss of attachment exceeded $5 \mathrm{~mm}$ for $95 \%$ of the experimental teeth. Foci of dental calculus were present on the roots of $85 \%$ of the teeth and dental plaque was present on the root surfaces of all teeth.

Periodontally healthy, caries-free teeth $(n=15)$ were used as controls in order to determine the number of bacteria introduced during manipulation of the teeth, the pulp and dentin samples. This group included 13 third molars and two lower premolars. All third molars were impacted and unerupted at the time when they were removed surgically. Both lower premolars were sound teeth that were extracted for orthodontic reasons. All teeth in the control group were extracted from young individuals and had incompletely formed apical regions. Clinically detectable plaque and calculus were absent on these teeth.

All extractions were performed under local anesthesia. Care was taken to avoid mechanical damage to the interdental root surfaces. Immediately after extraction, blood and saliva were removed by rinsing the teeth with sterile $0.9 \%$ saline solution. In an effort to minimize contamination of the dentin samples during further manipulation, the root surfaces were thoroughly scaled and root planed. This left the root surface free of bacterial plaque, calculus and remnants of periodontal ligament fibers. Subsequently, the teeth were stored in individual vials containing reduced transport fluid without EDTA (RTF) ${ }^{24}$ for less than 15 minutes until the dentin samples were collected.

Preparation of dentin samples. The dentin samples were prepared using a modification of a technique described by Edwardsson. ${ }^{25} \mathrm{~A}$ sterile diamond disk running at low speed was used to cut a first circumferential groove at the cementoenamel junction and a second circumferential groove at a distance of 2 to $3 \mathrm{~mm}$ from the apex. Subsequently, longitudinal grooves were cut in the buccal and in the lingual root surfaces. All grooves never exceeded a depth of $1 \mathrm{~mm}$. In addition, all grooves were made at a location several millimeters away from the site where the dentin samples would be taken. With a sterile splitting forceps, the crown was separated from the root. At that moment, the entire pulp or part of it was removed with a sterile forceps and transferred to RTF. A longitudinal buccolingual fracture of the root was then induced to expose the pulpal wall. Then the actual dentin samples that consisted of dentin shavings were collected by means of a round steel bur with a diameter of $1 \mathrm{~mm}$. The bur was run at low speed and a minimum of pressure was applied in an attempt to reduce the generation of frictional heat. The first dentin sample was taken from the pulpal wall at a level corresponding to the part of the root surface where the attachment loss had occurred. Subsequently, a total of three to five dentin samples, each representing a layer of approximately $1 \mathrm{~mm}$ in thickness, could be collected before the radicular surface was reached (Fig. 1).

From the healthy control teeth, 67 dentin samples from 19 interdental surfaces and 14 dental pulp samples were cultured. From the periodontally diseased teeth, 276 samples were cultured: 29 pulp samples and 247 dentin samples from 69 tooth surfaces. The latter consisted of 60 interdental surfaces and nine furcation areas.

The actual number of dentin samples collected from each root depended on the thickness of the radicular dentin. Statistical analysis of the cultural data showed that when more than one middle dentin layer was sampled, these data could be pooled. In this study, cultural data are reported for the samples from the pulp-tissue and for the samples obtained from the inner, middle and outer dentin layers. The inner dentin layer represented the dentin layer in contact with the dental pulp, whereas the outer dentin layer represented the dentin in contact with the subgingival environment.

\section{PROTOCOL USED TO CULTURE ROOT SURFACE DENTINE}
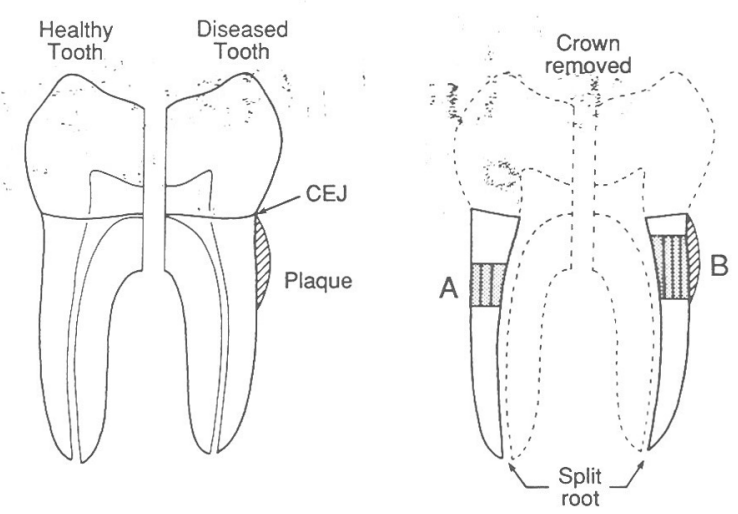

A

Non Plaque Covered Root Surface
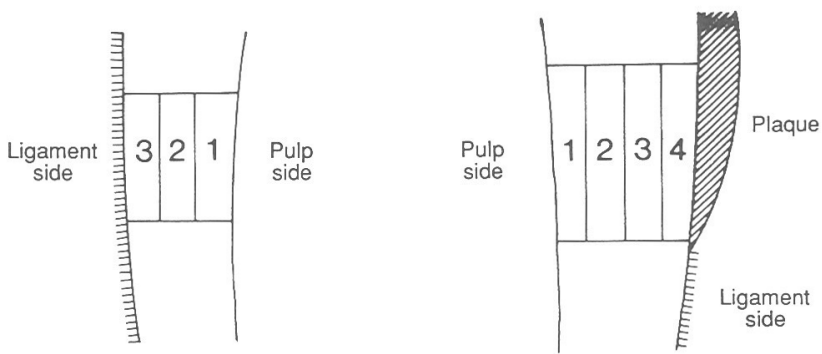

Figure 1. Protocol used to sample the radicular dentin. The samples were taken from the pulp tissue and from the radicular dentin. The dentin samples were taken from an interdental surface in the subgingival portion of the root. Three to five successive dentin layers were sampled, starting at the pulpal side. 
For the calculation of the mean values of the pulp samples from the periodontally diseased teeth, two samples were excluded. Both had bacterial concentrations greater than $10^{6}$ colony-forming units per milligram (CFU/mg) of tissue. One tooth was an upper central incisor with a 9-mm attachment loss; the other tooth was an upper first molar with a $12-\mathrm{mm}$ attachment loss on the sampled surface. Both teeth had clinically diagnosed necrosis of the pulp. Due to the extensive attachment loss it could not be ruled out that the pulpal necrosis was induced by periodontal bacteria entering the pulp chamber through the apical region.

Bacteriologic Procedures. The wet weight of the pulp samples and the individual dentin samples was determined, which allowed for the calculation of the number of $\mathrm{CFU} / \mathrm{mg}$ of tissue. Each sample was placed in an individual glass vial containing $2.5 \mathrm{ml}$ of RTF. The vials were transferred into an anaerobic chamber* for dispersion lasting 20 seconds using a Tekmar homogenization instrument $\dagger$ followed by sonication for five seconds using a Kontes sonicator. $\$^{26}$ The samples were plated semi-automatically with a spiral plater§ on selective and nonselective media. The nonselective enriched trypticase soy agar (ETSA) plates ${ }^{27}$ supported the growth of the anaerobic bacterial flora and yielded total counts for CFU. The sucrose-fermenting, facultative anaerobic bacteria were enumerated on ETSA-plates containing $20 \mathrm{mg} / \mathrm{ml}$ of sucrose and $10 \mu \mathrm{g} / \mathrm{ml}$ of metronidazole. ${ }^{28}$ Actinomyces viscosus and $A$. naeslundii were enumerated on CFAT-agar plates. ${ }^{29}$ MM10-agar plates without sucrose ${ }^{30}$ allowed for the enumeration of the asaccharolytic bacteria. All plates were incubated in an anaerobic chamber at $34^{\circ} \mathrm{C}$ for seven days. The CFU were enumerated, and the morphology of the different colony types was described. From each colony type representative colonies were picked for further identification. The identification of the bacterial isolates will be reported in a separate paper. ${ }^{31}$

Weighing Procedure. The glass vials containing $2.5 \mathrm{ml}$ of RTF were weighed twice before the collection of the sample. Subsequently, after the sample was added, the weighing procedure was repeated twice. Mean values of the duplicate measurements were used to determine the weight of each sample. The reproducibility of the weighing procedure was tested on 215 samples. The differences between duplicate weight determinations were tested for statistical significance using Student's $t$ test for paired samples. In addition, Pearson's correlation coefficients were calculated.

Sample Dispersion Methods. The effect of sonication following homogenization on the particle size of the dentin in the plated sample and on the recovery of

\footnotetext{
* Coy Laboratory Products, Ann Arbor, MI.

$\uparrow$ Tekmar Instruments, Cincinnati, $\mathrm{OH}$.

$\ddagger$ Kontes Glass Co, Vinewood, NJ.

$\S$ Spiral System, Inc, Cincinnati, OH.
}

CFU's was tested on 17 dentin samples. These samples were dispersed for 20 seconds with the Tekmar homogenizer. The sample was divided into two equal parts, one of which was plated immediately, while the other was sonicated for five seconds with the Kontes sonicator before being plated. From each of both samples, $10 \mu \mathrm{l}$ were examined in a Petroff-Hauser counting chamber to determine the size distribution of 100 dentin particles. The results were subjected to Chi-square analysis, Student's $t$ test for paired samples and Wilcoxon's signed rank test for paired samples. The cut-off point for statistical significance was $P=0.01$.

\section{RESULTS}

Reproducibility of the Sample-weighing Procedure. No statistically significant differences $(P>0.05)$ were found between repeated measurements of the vials without samples and between repeated measurements of the vials containing the pulp or dentin samples. The mean percentage difference between repeated measurements of the vials containing $2.5 \mathrm{ml}$ of RTF was $2.45 \%$ $\pm 2.32 \%$ (average \pm standard deviation). For the vials containing $2.5 \mathrm{ml}$ of RTF and the pulp or dentin sample, the mean percentage difference between the repeated measurements was $2.44 \% \pm 2.41 \%$. A correlation coefficient $r=0.99$ was found in both instances and both were statistically significant $(P<0.001)$.

Effect of Homogenization and Sonication. The frequency distribution of six groups of particle sizes is given in Table 1. Using parametric and nonparametric tests, statistically significant differences between Tekmar homogenization and Tekmar homogenization combined with sonication were found for four particle size groups. Comparing the distribution in both groups, significantly more small particles were found when the sample had been subjected to Tekmar dispersion combined with sonication (Chi-square, $P=0.0004$ ).

Of the 17 cultured samples in each group, bacterial growth was found in $23 \%$ of the samples treated with Tekmar homogenization and in $36 \%$ of those treated with Tekmar homogenization and Kontes sonication. The mean values for CFU/mg of tissue were $77 \pm 57$ (mean \pm standard deviation) and $237 \pm 294$, respectively. Although a tendency to obtain higher bacterial counts from the samples treated with both homogenization and sonication was apparent, this difference was not statistically significant (Student's $t$ test for paired samples: $P=0.34$ ).

Cultural Data for Periodontally Diseased and Healthy Control Teeth. In $87 \%$ of the periodontally diseased teeth, bacterial growth was detected within the dentin. Only $13 \%$ of the periodontally diseased, cariesfree teeth apparently had sterile dentin. The frequency distribution for the bacterial growth patterns in the pulp and dentin is given in Table 2. Nineteen different patterns were present for the diseased teeth. Eighty- 
Table 1

Percentage Distribution of Particle Sizes: Comparison between Tekmar Homogenization, and Tekmar Homogenization Combined with Sonication*

\begin{tabular}{llrrrrrr}
\hline & \multicolumn{5}{c}{ Particle size $(\mu \mathrm{m})$} \\
\cline { 3 - 7 } & & \multicolumn{1}{c}{2.5} & 5.0 & 7.5 & 10.0 & 25.0 & 50.0 \\
\hline \multirow{2}{*}{ Tekmar $(n=17)$} & Mean \% & 66.2 & 11.2 & 5.6 & 6.8 & 3.6 & 1.5 \\
& SEM & 2.4 & 1.7 & 0.6 & 0.9 & 0.6 & 0.4 \\
Tekmar + sonicator $(n=17)$ & Median & 69.3 & 10.0 & 5.7 & 6.5 & 2.9 & 1.2 \\
& Mean $\%$ & 86.0 & 7.5 & 1.9 & 1.8 & 1.1 & 1.3 \\
& SEM & 0.9 & 0.7 & 0.4 & 0.3 & 0.1 & 0.6 \\
Significance & Median & 86.1 & 7.5 & 1.6 & 1.8 & 1.0 & 0.3 \\
& & S & NS & S & S & S & NS \\
\hline
\end{tabular}

* $n$, number of samples; SEM, standard error of mean; Significance; significance of difference between both treatments, based on Student's $t$ test (paired samples) and Wilcoxon's signed rank test (paired samples); $\mathrm{S}, P<0.001 ; \mathrm{NS}, P>0.05$.

Table 2

Frequency Distribution of Bacterial Growth Patterns for Healthy and Diseased Teeth*

\begin{tabular}{|c|c|c|c|c|c|c|c|}
\hline \multicolumn{4}{|c|}{ Bacterial growth pattern } & \multicolumn{2}{|c|}{$\begin{array}{c}\text { Healthy } \\
\text { teeth }\end{array}$} & \multicolumn{2}{|c|}{$\begin{array}{l}\text { Diseased } \\
\text { teeth }\end{array}$} \\
\hline Pulp & Inner dentin & Middle dentin & Outer dentin & $n$ & $\%$ & $n$ & $\%$ \\
\hline- & - & - & - & 8 & 42.1 & 3 & 4.3 \\
\hline- & - & - & + & 1 & 5.3 & 5 & 7.2 \\
\hline- & - & + & + & & & 2 & 2.9 \\
\hline- & + & + & - & & & 1 & 1.5 \\
\hline- & + & + & + & & & $\hat{1}$ & 1.5 \\
\hline+ & - & - & - & 2 & 10.5 & 3 & 4.3 \\
\hline+ & - & - & + & & & 7 & 10.1 \\
\hline+ & - & + & - & & & 1 & 1.5 \\
\hline+ & + & - & - & 2 & 10.5 & & \\
\hline+ & - & + & + & & & 1 & 1.5 \\
\hline+ & + & + & - & & & 1 & 1.5 \\
\hline+ & + & - & + & 1 & 5.3 & 1 & 1.5 \\
\hline+ & + & + & + & & & 3 & 4.3 \\
\hline $\mathrm{N}$ & - & - & - & 4 & 21.0 & 6 & 8.7 \\
\hline $\mathrm{N}$ & - & - & + & & & 4 & 5.8 \\
\hline $\mathrm{N}$ & - & + & - & & & 1 & 1.5 \\
\hline $\mathrm{N}$ & + & - & - & 1 & 5.3 & 3 & 4.3 \\
\hline $\mathrm{N}$ & - & + & + & & & 7 & 10.1 \\
\hline $\mathrm{N}$ & + & - & + & & & 3 & 4.3 \\
\hline $\mathrm{N}$ & + & + & + & & & 16 & 23.2 \\
\hline Total & & & & 19 & 100.0 & 69 & 100.0 \\
\hline
\end{tabular}

${ }^{*} n$, number of teeth; $\%$, percentage of total number of teeth; $N$, not cultured; - , no bacterial growth detected; + , bacterial growth detected.

three percent of the diseased teeth displayed bacterial growth in the dentin: $31 \%$ contained bacteria in one dentin layer, $23 \%$ in two dentin layers and $29 \%$ in three dentin layers. From the teeth that contained bacterial growth in two dentin layers, $75 \%$ displayed growth in two adjacent dentin layers. In $59 \%$ of the periodontally diseased teeth from which the pulp tissue was cultured, bacterial growth was detected in the dental pulp samples.

Bacterial growth was detected in $37 \%$ of the healthy control teeth (Table 2). Seven different bacterial distribution patterns were present. In $11 \%$ of these teeth, bacteria could be cultured from the pulp tissue only, whereas in $16 \%$ of the teeth, bacteria were present in both the pulp and dentin. In $21 \%$ of the teeth, bacteria were present in one dentin layer, and in $5 \%$ two dentin layers contained bacteria. In none of the infected control teeth could bacterial growth be detected in dentin samples taken from the middle dentin layer. In $63 \%$ of the control teeth, no bacteria could be cultured from any of the sampled layers.

The bacterial densities in dentinal layers removed from diseased teeth were significantly higher than the densities found in the control teeth. In Table 3 the mean values are given for the total counts of viable bacteria present in the samples from healthy control teeth and periodontally diseased teeth. When the bacterial concentrations of the pulp samples and the corresponding dentin samples from healthy and diseased teeth were compared, statistically significantly higher concentrations were found in all samples from the diseased teeth (Wilcoxon's rank sum test for independ- 
ent samples, $P<0.05$ ). The mean bacterial concentration in the pulp and dentin layers from the diseased teeth was from 259 to 7,190 times greater than the concentrations in corresponding layers from healthy control teeth.

The frequency distribution of samples with bacterial growth in the different layers of healthy and diseased teeth is given in Table 4. The bacterial growth was subdivided in eight groups according to the bacterial concentration. In the few samples from the control teeth in which bacterial growth was present, the bacterial concentration was always less than $100 \mathrm{CFU} / \mathrm{mg}$ of tissue. In contrast, $49 \%$ of the pulp samples, $27 \%$ of the inner dentin samples, $19 \%$ of the middle dentin samples and $48 \%$ of the outer dentin samples taken from the periodontally diseased teeth contained more than $100 \mathrm{CFU} / \mathrm{mg}$ of tissue. No statistically significant differences (Chi-square test, $P=0.29$ ) were found between the different layers in the healthy teeth. However, when the different layers from the diseased teeth were compared, all differences, except between inner and middle layers, were statistically significant (Chi-square test, $P<0.01$ ).

In Table 5 the mean bacterial concentrations are given for the sampled layers from healthy and diseased teeth with different bacterial growth patterns. In the 20 teeth in which bacteria were found in all dentin layers, four different patterns existed for bacterial concentration changes from outer to inner dentin layers. In ten of these teeth, the bacterial concentration in the middle dentin layer was significantly lower when compared with the bacterial concentrations in the inner and outer dentin layer. In five teeth the bacterial concentration decreased linearly from the outer towards the inner dentin layers. In four teeth the bacterial concentration increased from outer towards inner dentin. In the remaining tooth the bacterial concentration in the middle dentin was higher than in all other layers. The first

Table 3

Total Counts of Viable Bacteria: Mean Values for Healthy Control Teeth and Periodontally Diseased Teeth*

\begin{tabular}{|c|c|c|c|c|c|}
\hline Teeth & Parameter & Pulp & Inner dentin & Middle dentin & Outer dentin \\
\hline \multicolumn{6}{|l|}{ Healthy } \\
\hline$n$ & & 14 & 19 & 19 & 19 \\
\hline Mean (CFU/mg) & & 5.4 & 7.6 & 0.0 & 2.3 \\
\hline SEM & & 3.7 & 4.9 & 0.0 & 1.7 \\
\hline Median & & 0 & 0 & 0 & 0 \\
\hline Minimum & & 0 & 0 & 0 & 0 \\
\hline Maximum & & 52 & 83 & 0 & 30 \\
\hline \multicolumn{6}{|l|}{ Diseased } \\
\hline$n$ & & 27 & 69 & 63 & 64 \\
\hline Mean (CFU/mg) & & $1,399.0$ & $2,263.0$ & $1,464.0$ & $16,537.0$ \\
\hline SEM & & 898.0 & 871.0 & 617.0 & $12,514.0$ \\
\hline Median & & 22 & 0 & 0 & 48.5 \\
\hline Minimum & & 0 & 0 & 0 & 0 \\
\hline Maximum & & $2.06 \times 10^{4}$ & $5.10 \times 10^{4}$ & $2.65 \times 10^{4}$ & $7.81 \times 10^{5}$ \\
\hline Wilcoxon & $P$ & 0.016 & 0.043 & 0.0002 & $<0.0001$ \\
\hline
\end{tabular}

* $\mathrm{n}$, number of samples; SEM, standard error of mean; Wilcoxon, Wilcoxon's rank sum test (independent samples); $P$, two-tailed probability (cut-off point: $P=0.05$ ).

Table 4

Frequency Distribution of Bacterial Concentration (CFU/mg Tissue) in Pulp and Dentin Samples of Healthy Control Teeth and Periodontally Diseased Teeth*

\begin{tabular}{|c|c|c|c|c|c|c|c|c|}
\hline \multirow{3}{*}{$\begin{array}{l}\text { Bacterial density } \\
\text { (CFU/mg) }\end{array}$} & \multicolumn{2}{|c|}{$\begin{array}{l}\% \text { of pulp } \\
\text { samples }\end{array}$} & \multicolumn{6}{|c|}{$\%$ of dentin samples } \\
\hline & \multirow{2}{*}{$\begin{array}{c}\mathrm{H} \\
(14)\end{array}$} & \multirow{2}{*}{$\begin{array}{c}\mathrm{D} \\
(29)\end{array}$} & \multicolumn{2}{|c|}{ Inner } & \multicolumn{2}{|c|}{ Middle } & \multicolumn{2}{|c|}{ Outer } \\
\hline & & & $\begin{array}{c}\mathrm{H} \\
(19)\end{array}$ & $\begin{array}{c}\mathrm{D} \\
(69)\end{array}$ & $\begin{array}{c}\mathrm{H} \\
(19) \\
\end{array}$ & $\begin{array}{c}\mathrm{D} \\
(62) \\
\end{array}$ & $\begin{array}{c}\mathrm{H} \\
(19) \\
\end{array}$ & $\begin{array}{c}\mathrm{D} \\
(69) \\
\end{array}$ \\
\hline 0 & 64 & 41 & 79 & 58 & 100 & 56 & 90 & 27 \\
\hline $1-20$ & 29 & 3 & 5 & 4 & 0 & 15 & 5 & 10 \\
\hline $21-100$ & 7 & 7 & 16 & 11 & 0 & 10 & 5 & 15 \\
\hline $10^{2}-10^{3}$ & 0 & 35 & 0 & 6 & 0 & 6 & 0 & 22 \\
\hline $10^{3}-10^{4}$ & 0 & 0 & 0 & 15 & 0 & 8 & 0 & 19 \\
\hline $10^{4}-10^{5}$ & 0 & 7 & 0 & 6 & 0 & 5 & 0 & 4 \\
\hline $10^{5}-10^{6}$ & 0 & 0 & 0 & 0 & 0 & 0 & 0 & 3 \\
\hline $10^{6}-10^{7}$ & 0 & 7 & 0 & 0 & 0 & 0 & 0 & 0 \\
\hline
\end{tabular}

${ }^{*} \mathrm{H}$, healthy control teeth; $\mathrm{D}$, periodontally diseased teeth; (), number of samples. 
mentioned pattern appeared again in the four teeth that displayed no bacterial growth for the middle dentin layer.

For the healthy control teeth, the mean values for pulp and all dentin samples were less than $10 \mathrm{CFU} / \mathrm{mg}$ of tissue. A maximum value of $83 \mathrm{CFU} / \mathrm{mg}$ was recorded for a single inner dentin sample. In the group of periodontally diseased teeth, the mean bacterial concentration ranged between 1,399 and $16,537 \mathrm{CFU} / \mathrm{mg}$ of tissue for the pulp and outer dentin samples, respectively. Within the dentin, the mean bacterial concentration for the middle dentinal layer was $36 \%$ lower than the mean bacterial concentration for the inner dentin and $91 \%$ lower than the mean bacterial concentration for the outer dentin.

The mean concentrations of facultative anaerobic bacteria, expressed as percentages of the total cultivable flora, are given in Table 6. Facultative anaerobic bac- teria could be cultured from four of the six control teeth that contained bacteria in one or more sampled layers. The flora obtained from one pulp sample, one inner dentin sample and two outer dentin samples, all from different teeth, contained small numbers of a purely anaerobic bacterial flora. The bacterial concentrations in these four samples ranged from six to 30 $\mathrm{CFU} / \mathrm{mg}$ of tissue. In the middle dentin layer, no bacterial growth could be found on any of the nonselective and selective media.

From the 63 periodontally diseased teeth from which bacteria could be cultured from one or more layers, 46 contained facultative anaerobic bacteria. The facultative anaerobes represented from $35 \%$ to $52 \%$ of the total viable flora. Facultative anaerobes could not be found in the flora cultured from nine pulp samples, nine inner dentin samples, ten middle dentin samples and 16 outer dentin samples.

Table 5

Mean Bacterial Concentrations (CFU/mg) in Samples from Healthy and Diseased Teeth with Different Patterns of Bacterial Invasion*

\begin{tabular}{|c|c|c|c|c|c|c|c|c|c|c|c|c|c|}
\hline \multicolumn{4}{|c|}{$\begin{array}{c}\text { Invasion } \\
\text { pattern }\end{array}$} & \multicolumn{10}{|c|}{ Bacterial concentration ( $\mathrm{CFU} / \mathrm{mg}$ ) } \\
\hline \multirow{2}{*}{$\mathbf{P}$} & \multirow{2}{*}{ I } & \multirow{2}{*}{$\mathbf{M}$} & \multirow{2}{*}{$\mathrm{O}$} & \multicolumn{5}{|c|}{ Healthy teeth } & \multicolumn{5}{|c|}{ Diseased teeth } \\
\hline & & & & Pulp & Inner & Middle & Outer & $\bar{n}$ & Pulp & Inner & Middle & Outer & $n$ \\
\hline- & - & - & - & 0 & 0 & 0 & 0 & (8) & 0 & 0 & 0 & 0 & (3) \\
\hline- & - & - & + & 0 & 0 & 0 & 14 & (1) & 0 & 0 & 0 & 920 & $(5)$ \\
\hline- & - & + & + & & & & & & 0 & 0 & 10322 & 3400 & (2) \\
\hline- & + & + & - & & & & & & 0 & 20 & 6 & 0 & (1) \\
\hline- & + & + & + & & & & & & 0 & 980 & 52 & 37 & (1) \\
\hline+ & - & - & - & 29 & 0 & 0 & 0 & (2) & 228 & 0 & 0 & 0 & (3) \\
\hline+ & - & - & + & & & & & & 2163 & 0 & 0 & 514 & (7) \\
\hline+ & - & + & - & & & & & & 420 & 0 & 2946 & 0 & (1) \\
\hline+ & + & - & - & 5 & 28 & 0 & 0 & (2) & & & & & \\
\hline+ & - & + & + & & & & & & 249 & 0 & 1081 & 1028 & (1) \\
\hline+ & + & + & - & & & & & & 20606 & 33 & 64 & 0 & (1) \\
\hline+ & + & - & + & 7 & 83 & 0 & 30 & (1) & 474 & 21 & 0 & 64 & (1) \\
\hline+ & + & + & + & & & & & & 200 & 2348 & 83 & 9399 & (3) \\
\hline $\mathbf{N}$ & - & - & - & $\mathrm{N}$ & 0 & 0 & 0 & (4) & $N$ & 0 & 0 & 0 & (6) \\
\hline $\mathrm{N}$ & - & - & + & & & & & & $\mathrm{N}$ & 0 & 0 & 374 & (4) \\
\hline $\mathbf{N}$ & - & + & - & & & & & & $\mathrm{N}$ & 0 & 18 & 0 & (1) \\
\hline $\mathbf{N}$ & + & - & - & $\mathrm{N}$ & 6 & 0 & 0 & (1) & $\mathrm{N}$ & 481 & 0 & 0 & (3) \\
\hline $\mathrm{N}$ & - & + & + & & & & & & $\mathrm{N}$ & 0 & 281 & 3087 & (7) \\
\hline $\mathrm{N}$ & + & - & + & & & & & & $\mathrm{N}$ & 1814 & 0 & 3111 & (3) \\
\hline $\mathbf{N}$ & + & + & + & & & & & & $\mathrm{N}$ & 7539 & 3827 & 14896 & (16) \\
\hline
\end{tabular}

*P, pulp; I, inner dentin; M, middle dentin; $\mathrm{O}$, outer dentin; $n$, number of teeth; $\mathrm{N}$, not cultured; -, no bacterial growth detected; + , bacterial growth detected.

Table 6

Proportion of Facultative Bacteria (Mean Percentages of Total Cultivable Flora) in Pulp and Dentin Samples from Healthy Control Teeth and Periodontally Diseased Teeth

\begin{tabular}{ccccc}
\hline \multirow{2}{*}{ Teeth } & \multirow{2}{*}{ Pulp } & \multicolumn{3}{c}{ Dentin } \\
\cline { 3 - 5 } & & Inner & Middle & Outer \\
\hline Healthy & $68(100)^{*}$ & $48(75)$ & $-\dagger$ & $0(0)$ \\
Diseased & $35(47)$ & $52(69)$ & $44(65)$ & $46(72)$ \\
\hline
\end{tabular}

* Percentages of positive samples from which facultative bacteria could be cultured.

$\dagger$ No growth on ETSA plates. 


\section{DISCUSSION}

In this study it has been demonstrated that significant numbers of viable bacteria are present throughout the radicular dentin of periodontally diseased, caries-free human teeth. In addition, it has been shown that the dental pulp of many of these teeth may contain significant numbers of bacteria. These results have confirmed and extended our microscopic observations that bacteria are present in the dentinal tubules beneath the plaque covering the roots of periodontally diseased teeth. ${ }^{5}$

The methodology allowed the calculation of the bacterial concentration in the different samples as CFU/ $\mathrm{mg}$ of tissue. Consequently, bacterial concentrations from different samples could validly be compared. When compared with Tekmar homogenization, the combined use of homogenization and sonication resulted in both smaller dentin particles and higher counts for CFU. This effect is probably due to a combination of further mechanical reduction of the dentin particles and the breaking up of clumped particles. The result of both actions was the dispersion of bacteria that were initially trapped inside the dentin shavings. These data are in agreement with the results of studies on the influence of different dispersive treatments on the recovery of the bacteria present in plaque samples. ${ }^{26,32}$

The small numbers of bacteria isolated from a limited number of dentin and pulp samples from the healthy control teeth could have been introduced as the result of mechanical manipulations accompanying the extraction procedure. These teeth would be prone to this phenomenon, since all had incompletely formed apices. The fact that when bacterial growth occurred in these teeth it was in samples from the pulp tissue or from the inner or outer dentin would further substantiate this hypothesis.

Bacterial invasion in the tubules of the radicular dentin of periodontally diseased teeth has been reported in microscopic studies in humans. ${ }^{5,21-23}$ In experimental studies on periodontal disease in rats, ${ }^{33,34}$ in hamsters ${ }^{34,35}$ and in cats, ${ }^{36}$ bacterial invasion into exposed radicular dentin was described. In the experimental studies in animals, the bacterial invasion in the radicular dentin was accompanied by tissue destruction similar to root caries. However, in the present study and in a previously reported scanning electron microscopic study, ${ }^{5}$ no clinically detectable carious lesions were present in the exposed root surfaces.

The high levels of bacteria in the outer dentinal layer are explained by the local invasion of subgingival plaque bacteria into the dentinal tubules. ${ }^{5}$ However, the presence of bacteria in the deeper dentinal layers indicates that these plaque bacteria can migrate considerable distances within the dentin. This observation is in agreement with results of previous in vitro experiments in which subgingival plaque bacteria penetrated into the dentinal tubules to a mean depth of $125 \mu \mathrm{m}$ in a period of six days..$^{37,38}$ It was of interest to observe a drop in the bacterial concentration in the middle dentin layer of 14 of the periodontally diseased teeth. Bacteria in this dentin layer have to derive their nutrients from substances diffusing either from the pulp or from the subgingival environment. It seems logical that limited nutrient availability is responsible for the decreased numbers of bacteria in the middle dentin layer. The increased numbers of bacteria in the inner layer could reflect that the odontoblast processes acted as a mechanical barrier for the microorganisms migrating towards the dental pulp. In mature teeth the odontoblast processes extend into the inner third of the dentinal tubules, which would roughly correspond with the inner dentin layer referred to in this study (for review: see Reference 39). Since the bacterial migration towards the pulp would be hampered at the interface with the odontoblast process, it is tempting to suggest that the increased bacterial concentration in the inner dentin layer would be the result of blockage causing local proliferation of bacteria.

Bacterial invasion could not be detected in $13 \%$ of the diseased teeth. A number of reasons for this absence of bacteria could be found, such as the absence of radicular resorption lacunae, ${ }^{4,5}$ composition of the subgingival bacterial flora or the presence of a mineralized cuticle. ${ }^{40,41}$ However, more likely, the bacterial concentrations present in these teeth might have been below the detection limit of the bacteriological technique. Finally, as evidenced from four teeth from which both the interdental and the furcation areas were sampled (data not reported), bacterial invasion in the radicular structures can be limited to a specific area.

However, the radicular dentin and cementum of the majority of the examined periodontally diseased, cariesfree human teeth contained significant numbers of viable bacteria. Consequently, these radicular structures are likely to serve as bacterial reservoirs ${ }^{42}$ from which bacterial recolonization of the mechanically treated root surfaces can occur. This phenomenon could change the current concepts concerning root surface debridement.

For the treatment of the root surfaces of periodontally diseased teeth, aggressive scaling and root planing have been advocated (for review: see References 43 and 44). The rationale for this approach was the creation of a "biologically acceptable" root surface ${ }^{45}$ by removing all adherent mineralized and nonmineralized bacterial plaque, as well as the diseased cementum that would contain endotoxin ${ }^{46-48}$ and other bacterial toxic substances. However, this "endotoxin concept" has recently been challenged as being based on the results of incorrectly used technical procedures for the detection of endotoxin. ${ }^{49-52}$ Although the removal of cementumassociated bacterial toxins might be of importance for the outcome of periodontal therapy, it has been dem- 
onstrated that even the mechanical removal of all subgingival calculus and plaque is often impossible, since anatomical structures of the root and radicular resorption lacunae that are filled with bacteria are inaccessible for instrumentation. ${ }^{3-5,53}$ It is clear that bacteria that deeply invaded the radicular dentin, as has been shown in this study, are even more inaccessible for mechanical therapy.

If this is the case, then such aggressive scaling and root planing might be counterproductive for the health of the periodontally diseased tooth. Indeed, this procedure would shorten the distance that bacteria would have to traverse before reaching the pulpal tissues. Cultural studies of the bacterial flora found in necrotic pulp tissue have suggested that the bacteria resemble those isolated from subgingival plaque samples. ${ }^{31,54-57}$ Thus it is conceivable that the subgingival plaque is the origin of these pulpal infections. Consequently, one of the goals of periodontal therapy should be to minimize this bacterial invasion. This can be accomplished by therapeutic procedures that may kill the invading bacteria in situ. A systemic antimicrobial compound might be able to diffuse from the pulp into the dentin in sufficient concentration to kill those bacteria that have accumulated in the dentinal tubules adjacent to the pulp. Simultaneously, a slow release delivery system placed in the subgingival pocket might deliver sufficiently high concentrations of the antimicrobial drug in order to kill the bacteria that have invaded the outer dentin layer.

Bacterial invasion was observed in $87 \%$ of the examined periodontally diseased teeth. Aggressive scaling and root planing might have reduced this to $74 \%$ by eliminating the group in which bacteria were found in only the outer dentin layer. If such a high percentage of treated teeth contains viable bacteria in the dentin and pulp tissue that can thereby act as a bacterial reservoir from which the root surface could be recolonized, then the question arises as to whether this reservoir can contribute to some of the failures of periodontal therapy. Concurrently, the question arises as to whether all of these teeth will develop pulpal pathoses. It is of interest that none of the 17 patients whose teeth had an infected dental pulp exhibited or complained of pulpal problems. It could be that a threshold bacterial concentration is necessary before inflammatory reactions of the periodontal or pulpal tissues are induced. Most likely the composition of the invading bacterial flora will be of critical importance. However, currently available data do not allow for final answers to these questions.

\section{REFERENCES}

1. Zambon, J. H., Reynolds, H. S., and Slots, J.: Black-pigmented Bacteroides spp. in the human oral cavity. Infect Immun 32: 198, 1981.
2. Van der Velden, U., Van Winkelhoff, A. J., Abbas, F., and De Graaff, J.: The habitat of periodontopathic microorganisms. J Clin Periodontol 13: 243, 1986.

3. Lindskog, S., and Blomlöf, L.: Cementum hypoplasia in teeth affected by juvenile periodontitis. J Clin Periodontol 10: 443, 1983.

4. Schroeder, H. E., and Rateitschak-Plüss, E.: Focal root resorption lacunae causing retention of subgingival plaque in periodontal pockets. Schweiz Monatsschr Zahnmed 93: 1033, 1983.

5. Adriaens, P. A., and De Boever, J. A.: Ultrastructural study of bacterial invasion in roots of periodontally diseased, caries-free human teeth. J Dent Res 65: 770, 1986.

6. Listgarten, M.: Electron microscopic observations on the bacterial flora of acute necrotizing ulcerative gingivitis. $J$ Periodontol 36: 328,1965

7. Heylings, R. T.: Electron microscopy of acute ulcerative gingivitis (Vincent's type). Demonstration of the fuso-spirochaetal complex of bacteria within pre-necrotic gingival epithelium. $\mathrm{Br}$ Dent $J$ 122: $51,1967$.

8. Courtois, G., Cobb, C., and Killoy, W.: Acute necrotizing ulcerative gingivitis. A transmission electron microscope study. $J$ Periodontol 54: 671, 1983.

9. Takeuchi, H., Sumitani, M., Tsubakimoto, K., and Tsutsui, M.: Oral microorganisms in the gingiva of individuals with periodontal disease. J Dent Res 53: 132, 1974.

10. Frank, R., and Voegel, J.: Bacterial bone resorption in advanced cases of human periodontitis. $J$ Periodont Res 13: 251, 1978.

11. Frank, R.: Bacterial penetration in the apical pocket wall of advanced human periodontitis. J Periodont Res 15: 563, 1980.

12. Saglie, F. R., Newman, M., Carranza, F., and Pattison, G.: Bacterial invasion of gingiva in advanced periodontitis in humans. $J$ Periodontol 53: 217, 1982.

13. Pekovic, D. D., and Fillery, E. D.: Identification of bacteria in immunopathological mechanisms of human periodontal disease. J Periodont Res 19: 329, 1984.

14. Manor, A., Lebendiger, M., Shiffer, A., and Tovel, H.: Bacterial invasion of periodontal tissues in advanced periodontitis in humans. J Periodontol 55: 567, 1984.

15. Saglie, F. R., Carranza, F. A., and Newman, M. G.: The presence of bacteria within the oral epithelium in periodontal disease. I. A scanning and transmission electron microscopic study. $J$ Periodontol 56: 618, 1985.

16. Gillett, R., and Johnson, N.: Bacterial invasion of the periodontium in a case of juvenile periodontitis. $J$ Clin Periodontol 9: 93, 1982.

17. Saglie, F. R., Carranza, F. A., Newman, M. G., et al.: Identification of tissue-invading bacteria in human periodontal disease. $J$ Periodont Res 17: 452, 1982.

18. Carranza, F. A., Saglie, F. R., Newman, M. G., and Valentin, P. L.: Scanning and transmission electron microscopic study of tissueinvading microorganisms in localized juvenile periodontitis. $J$ Periodontol 54: 598, 1983.

19. Zander, H.: The attachment of calculus to root surfaces. $J$ Periodontol 24: 16, 1953.

20. Daly, C., Seymour, G., Kieser, J., and Corbet, E.: Histological assessment of periodontally involved cementum. J Clin Periodontol 9: $266,1982$.

21. Miller, W. D.: The Micro-Organisms of the Human Mouth. The Local and General Diseases Which Are Caused by Them. Philadelphia, S. S. White Dental Manufacturing, 1890.

22. Kopczyk, R., and Conroy, C.: The attachment of calculus to root planed surfaces. Periodontics 6: 78, 1968.

23. Langeland, K., Rodrigues, H., and Dowden, W.: Periodontal disease, bacteria and pulpal histopathology. Oral Surg 37: 257, 1974.

24. Syed, S. A., and Loesche, W. J.: Survival of human dental plaque flora in various transport media. Appl Microbiol 24: 638, 1972.

25. Edwardsson, S.: Bacteriological studies on deep areas of carious dentine. Odont Revy (suppl. 32) 25: 1, 1974. 
26. Syed, S. A., and Loesche, W. J.: Efficiency of Kontes ultrasonic cell disruptor in the dispersion of dental plaque and pure cultures of oral flora. $J$ Dent Res 57: 320, 1978.

27. Syed, S., Svanberg, M., and Svanberg, G.: The predominant cultivable dental plaque flora of beagle dogs with gingivitis. $J$ Periodont Res 15: 123, 1980.

28. Loesche, W. J., Syed, S. A., Laughon, B., and Stoll, J.: The bacteriology of acute necrotizing ulcerative gingivitis. $J$ Periodontol 53: 223, 1982.

29. Zylber, L., and Jordan, H.: Development of a selective medium for detection and enumeration of Actinomyces viscosus and Actinomyces naeslundii in dental plaque. J Clin Microbiol 15: 253, 1982.

30. Loesche, W. J., and Straffon, L.: Longitudinal investigation of the role of Streptococcus mutans in human fissure decay. Infect Immun 26: 498, 1979.

31. Adriaens, P. A., and Loesche, W. J.: Bacterial flora invading the radicular dentin and pulp of periodontally diseased human teeth. A bacteriological study. $J$ Dent Res (submitted).

32. Salvador, S. L., Syed, S. A., and Loesche, W. J.: The isolation of Treponema denticola from subgingival plaques. $J$ Dent Res 65: $178,1986$.

33. Fitzgerald, R., Jordan, H., and Stanley, H.: Experimental caries and gingival pathologic changes in the gnotobiotic rat. $J$ Dent Res 39: 923, 1960.

34. Jordan, H., Keyes, P., and Bellack, S.: Periodontal lesions in hamsters and gnotobiotic rats infected with actinomyces of human origin. J Periodont Res 7: 21, 1972.

35. Keyes, P., and Jordan, H.: Periodontal lesions in the Syrian hamster. III. Findings related to an infectious and transmissible component. Arch Oral Biol 9: 377, 1964.

36. Ryan, P., Newcomb, G., Seymour, G., and Powell, R.: The pulpal response to citric acid in cats. J Clin Periodontol 11: 633, 1984.

37. Adriaens, P. A., Claeys, G., and J. De Boever, J. A.: Scanning electron microscopic observations on the in vitro colonization of human dentin by Capnocytophaga gingivalis. Caries Res 16: 367, 1982.

38. Adriaens, P. A., Claeys, G., and De Boever, J. A.: Colonization of human dentin by a mixed flora of oral bacteria, in vitro. Caries Res 18: 160, 1984.

39. Adriaens, P. A.: Ultrastructural Aspects of Dentin and Its Bacterial Invasion. Thesis. State University of Ghent, Ghent, 1982.

40. Eide, B., Lie, T., and Selvig, K. A.: Surface coatings on dental cementum incident to periodontal disease. I. A scanning electron microscopic study. J Clin Periodontol 10: 157, 1983.

41. Eide, B., Lie, T., and Selvig, K. A.: Surface coatings on dental cementum incident to periodontal disease. II. Scanning electron microscopic confirmation of a mineralized cuticle. J Clin Periodontol 11: $565,1984$.

42. Loesche, W. J.: Clinical and microbiological aspects of chem- otherapeutic agents used according to the specific plaque hypothesis. $J$ Dent Res 58: 2404, 1979.

43. Wirthlin, M.: The current status of new attachment therapy. J Periodontol 52: 529, 1981.

44. O'Leary, T. J.: The impact of research on scaling and root planing. J Periodontol 57: 69, 1986.

45. Ramfjord, S. P.: Root planing and curettage. Int Dent $J$ 30: 93, 1980.

46. Hatfield, C., and Baumhammers, A.: Cytotoxic effects of periodontally involved surfaces of human teeth. Arch Oral Biol 16: 465,1971 .

47. Aleo, J., De Renzis, F., Farber, P., and Varboncoeur, A.: The presence and biological activity of cementum-bound endotoxin. $J$ Periodontol 45: 672, 1974.

48. Aleo, J., De Renzis, F., and Farber, P.: In vitro attachment of human gingival fibroblasts to root surfaces. $J$ Periodontol 46: 639, 1975.

49. Fine, D., Kessler, R., Tabak, L., and Shockman, G.: Limulus lysate activity of lipoteichoic acids. J Dent Res 56: 1500, 1977.

50. Adelson, L., Hanks, C., Ramfjord, S., and Caffesse, R.: In vitro cytotoxicity of periodontally diseased root surfaces. $J$ Periodontol 51: 700, 1980.

51. Nakib, N., Bissada, N., Simmelink, J., and Goldstine, S.: Endotoxin penetration into root cementum of periodontally healthy and diseased human teeth. J Periodontol 53: 368, 1982.

52. Ito, K., Hindman, R., O'Leary. T., and Kafrawy, A.: Determination of the presence of root-bound endotoxin using the local Schwartzman phenomenon (LSP). J Periodontol 56: 8, 1985.

53. Waerhaug, J.: Healing of the dento-epithelial junction following subgingival plaque control. II. As observed on extracted teeth. $J$ Periodontol 49: 119, 1978.

54. Kantz, W. E., and Henry, C. A.: Isolation and classification of anaerobic bacteria from intact pulp chambers of non-vital teeth in man. Arch Oral Biol 19: 91, 1974.

55. Zavistoski, J., Dzink, J. A., Onderdonk, A., and Bartlett, J.: Quantitative bacteriology of endodontic infections. Oral Surg 49: $171,1980$.

56. Kipioti, A., Nakou, M., Legakis, N., and Mitsis, F.: Microbiological findings of infected root canals and adjacent periodontal pockets in teeth with advanced periodontitis. Oral Surg 58: 213, 1984.

57. Adriaens, P. A., Loesche, W. J., and De Boever, J. A.: Bacteriology of the flora present in the roots of periodontally diseased teeth. $J$ Dent Res 66: 338, 1987.

Send reprint requests to: Patrick A. Adriaens, State University of Ghent, School of Dentistry, Department of Fixed Prosthetics and Periodontology, University Hospital, De Pintelaan 185, B-9000 Ghent, Belgium. 